\title{
Biyobenzer Ürünlerde Klinik Uygulamada Karşılaşılabilecek Sorunlar
}

\author{
Fatma Ceyda KORUCU, Hakan NAZLI, Gülşah GEDİK, İran ÇİÇİN
}

\begin{abstract}
ÖZET
Biyofarmasötikler, biyoteknoloji kullanılarak biyolojik kaynaklardan elde edilen büyük ve kompleks ilaçlardır. Biyofarmasötiklerin üretiminde, canlı organizmaların kullanılması ve üretim yöntemlerinin kompleks olması nedeniyle aynı üreticinin yaptığı farklı serilerde bile farklılıklar oluşmaktadır. Dolayısı ile farklı üreticiler ancak orjinal moleküle benzer moleküller üretebilirler, biyobenzer tanımı da bu farklılıkları ortaya koymak için kullanılmaktadır. Günümüzde biyobenzer ilaçlar kanser, hematolojik hastalıklar ve endokrin hastalıkları başta olmak üzere birçok hastalığın tedavisinde
\end{abstract}

kullanılmaktadır. Biyobenzerlerin tedavide daha sık kullanılması ve pazar payının büyümesi patent süresi dolan bu ürünlerin kopyalarının üretilmesini teşvik etmektedir. Ruhsatlandırma sürecinde yapılan çalışmalarda amaç biyobenzerlerin orjinatörden daha iyi olduğunun kantlanmasından çok, orjinatöre yapı, güvenlik, etkinlik benzerliğinin gösterilmesidir. Biyofarmasötik ürünler için klinik uygulamada karşılaşılan en büyük sorun immunojenesitedir ve ilaç güvenliğini, etkinliğini etkileyebilir. Klinik uygulamalarda sağlık otoriterleri maliyet, hasta yararı, belirsizlikler dengesini iyi kurmalıdır.

Anahtar Kelimeler: Biyofarmasötikler; biyobenzer ilaçlar; immunojenisite; klinik kullanım.
Hakan Nazlı

Trakya Üniversitesi, Eczacilık Fakültesi, Farmasötik Teknoloji ABD, EDİRNE

e-mail:hakannazli@trakya.edu.tr

Gülşah Gedik

Trakya Üniversitesi, Eczacılık Fakültesi, Farmasötik Teknoloji ABD, EDİRNE

e-mail: gulsahgedik@trakya.edu.tr

İrfan Çiçin

Trakya Üniversitesi, Tip Fakültesi, Medikal Onkoloji BD, EDİRNE

e-mail:irfancicin@hotmail.com

Sorumlu Yazar:

Fatma Ceyda Korucu

Trakya Üniversitesi Sağlik Araştırma ve Uygulama Merkezi, EDİRNE

e-mail: fceydakorucu@trakya.edu.tr

Tel: 05337424340

\section{Gíriş}

Biyofarmasötikler, biyoteknoloji kullanılarak yaşayan organizmalardan kontrollü gen ekspresyonu, rekombinant DNA teknolojisi, antikor üretim teknikleri ile elde edilen ilaçlardır. Nonbiyolojik ya da kimyasallar ajanlardan temel farklarının ve kullanımlarındaki özel yaklaşımlarının temelinde canlıdan elde edilmesine dayanan özellikleri yatmaktadır. Üretici firma tarafından kendi teknolojisi ile bir konak hücresinin (mantar, bakteri veya memeli hücresi) genlerine üretilmesi arzu edilen proteinin genetik materyali eklenir ve konak hücre kendi proteinleri gibi üretilmesi istenen proteinleri de üretir. $\mathrm{Bu}$ hücreler daha sonra çoğaltılarak "master cell bank" oluşturulur ve kaynak olarak kullanılır. Biyoreaktörler içinde uzun üretim süresince konak hücrelerin ürettiği biyolojik ürünler ayrıştırılır, saflaştııılır, karekterizasyon ve stabilite çalışmaları yapılır, çok sayıda kalite kontrol testleri uygulanır, ilaç haline formüle edilir, toksikolojik ve biyoeşdeğerlik çalışmaları yapılır ve ambalajlama işlemleri ile kullanıma hazır hale getirilir (Şekil 1). 


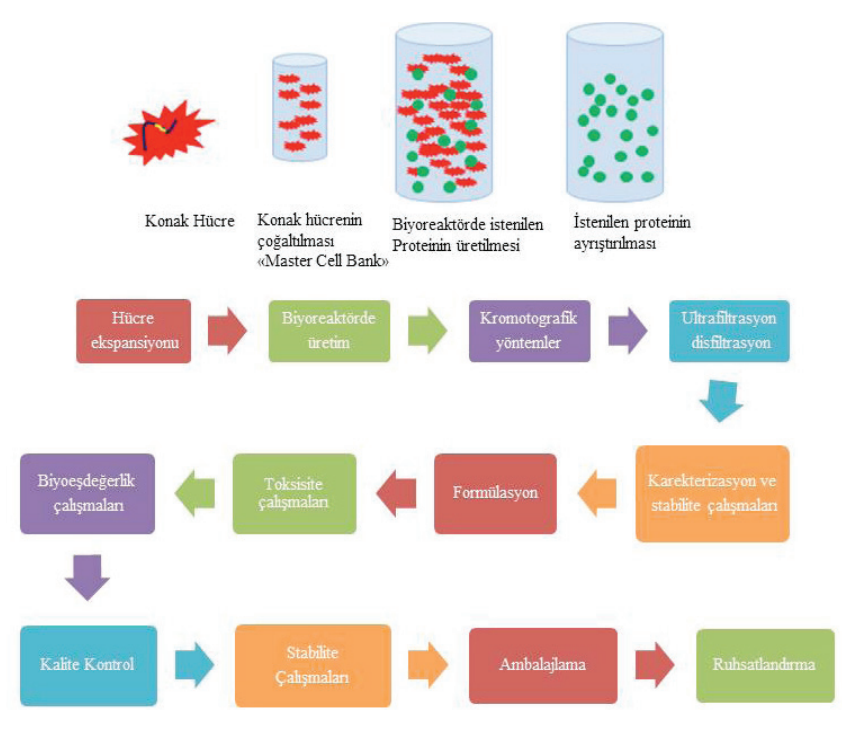

Şekil 1. Biyofarmasötik üretim aşamalarının genel şematizasyonu

Şekil 1'de bahsedilen ve şematize edilen aşamaların hemen hepsi kimyasal ilaçlardan farklı ve genellikle üretici firmaların özgün teknolojileri ile yapılmaktadır. Yine bahsedilen aşamaların her birinde konak hücrelerin kontrol dışı maruz kaldığı stres faktörleri, farklı operasyon koşulları, farklı hücre yapıları ve üreme ortamları dolayısılla ortam basıncı ve gaz düzeyleri gibi biyoreaktör koşulları, ayrıştırma işleminde kullanılan yöntemler ve maddelerin farklı bağlanma koşulları, karekterizasyon ve stabilite çalışmaları, referans standart maddeler gibi çok sayıda faktör üretilen proteinin yapısında, karbonhidrat zincirlerinin yapısında, immunojenisitede değişikliğe neden olarak biyofarmasötiğin yapısını etkileyebilmektedir Bu değişiklikler ilaç etkinliği ve yan etkiler açısından riskler oluşturmaktadır (Şekil 2) $(1,2)$.

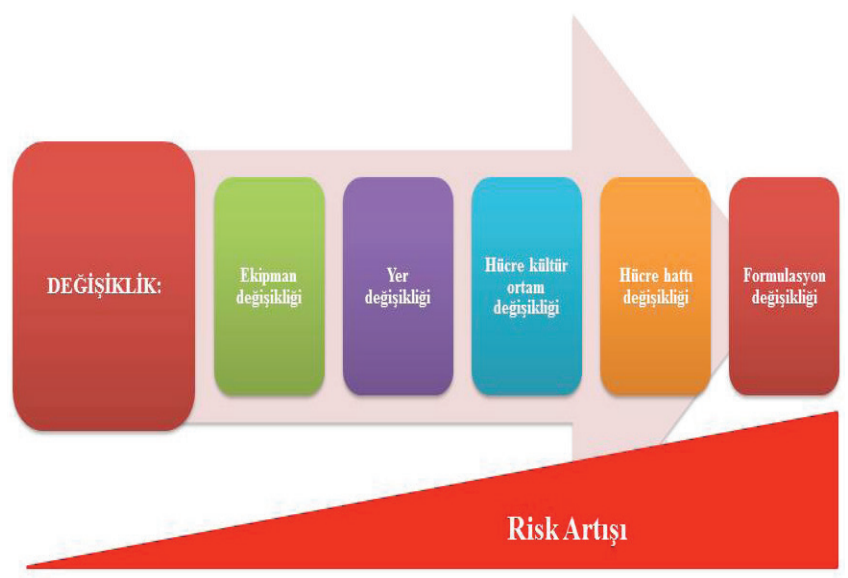

Şekil 2. Biyofarmasötik üretimini etkileyen faktörler ve ürün kalitesinin değişmesi riski
Şekil 2'de gösterilen süreç içinde meydana gelen gelişmelere bağlı değişiklikler ve özellikle konak hücredeki kaçınılmaz değişimler aynı üründe bile zaman içinde farklılaşmaya neden olur (mikroheterojenisite). Bu değişikliklerin ürün üzerine etkisi, özellikle içeriklerinde bulunan protein ve karbonhidrat yapılarının aydınlatılması ve zamanla değişimin gözlenmesi amacıyla testlerle denetlenir ve kontrol altında tutulur. Bu testlerden bazıları şunlardır:

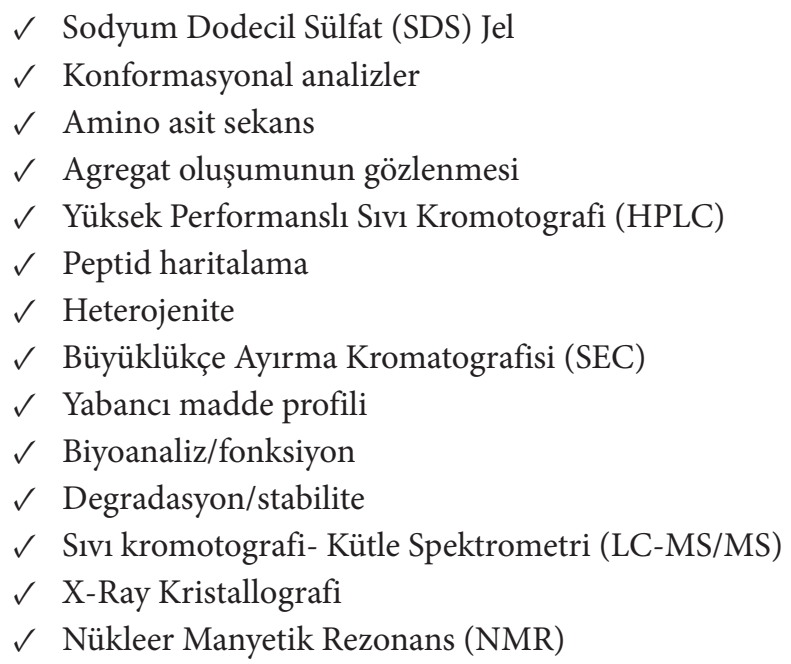

Biyofarmasötikler immunojen olmaları, ortam şartlarına bağlı özelliklerinin çok kolay değişebilir olması, stabil olmayan yapıda olmaları, çok büyük molekül olmaları ve en önemlisi canlı hücrelerden üretilmeleri ile kimyasal ilaçlardan ayrılırlar. Biyofarmasötiklerin farklı bir üretici tarafından aynı olmayan sistemler ve farklı hücre hattı kullanılması nedeniyle kimyasal ilaçlar gibi aynısı üretilemez. Hatta aynı firmanın ürettiği seriler arasında bile farklılıklar olabilir (3). Bununla birlikte, antikor gibi büyük moleküllerin yapısının tam olarak ortaya konması ve birebir aynısının yapılması da bugün için mümkün değildir. Dolayısı ile farklı üreticiler orjinal moleküle ancak benzer moleküller üretebilirler ki "biyobenzer" tanımı da bu farklılıkları ortaya koymak için kullanılmaktadır. Biyofarmasötiklerde ufak değişiklikler ilacın farmakokinetiğini, farmakodinamiği, immunojenisitesini ve etkinliğini etkileyebilmektedir. Biyobenzerler ile ilişkili temel sorun burada kendini göstermektedir; bu farklılıklar ilaç farmasötik formunu, veriliş yolunu dolayısıyla ilaç etkinliği ve güvenliğini ne ölçüde etkiler $(4,5)$ ?

\section{Biyobenzer Ürünlerde Klinik Uygulamada Karşıllaşılabilecek Sorunlar}

1. "State of the art". İster orjinatör olsun ister biyobenzer molekül bir biyofarmasötiğin üretim süreci, üst düzey teknoloji, yeterli deneyim, yeterli organizasyon ve üst düzey 
kalite uygulamaları gerektirir. Biyolojik ürünlerde temel konu ürün kalitesi ve bunun denetimidir. Maliyeti düşürmek amaçlı ortaya çıkan biyobenzer ürünlerde maliyetten kaçınmak amacıyla yüksek kalite ve standartlardan ödün verilmesi kabul edilemez. Sağlık otoriteleri için ve pratikte kullanımla ilgili en önemli sorun eşdeğerlik tartışması kadar biyobenzerlerin üretim sürecinde kalitenin sağlanması ve denetlenebilirliğidir.

2. İki biyobenzer molekülün mikroheterojenite nedeniyle zaman içinde daha da farklılaşması söz konusu olabilir mi? Aslında mikroheterojenite biyofarmasötik üretim disiplini içinde sorun olmaması gereken bir durumken üretim ihmalleri durumunda büyük problemlere yol açabilecek bir sorun olabilir (Şekil3). Bunun için uygun farmakokinetik çalışmalar yapılmalıdır ancak, mikroheterojenite nedeniyle bu çalışmalar yapilamıyorsa yerine uygun referans standartlarda farmakodinamik çalışmalar yapılmalıdır (6).

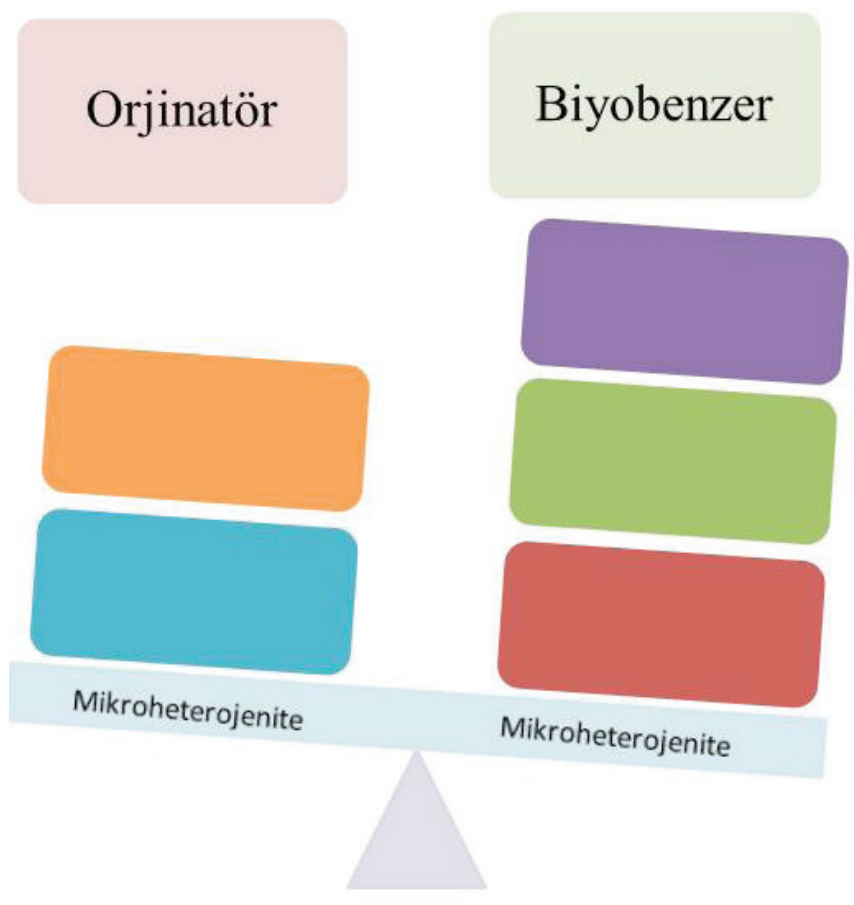

Şekil 3. Biyobenzerlerin zaman içinde farklılaşma riski: Biyobenzerlerde üretim süreçlerindeki değişikliklere bağlı olarak mikroheterojenite kaçınılmazdır. Ürün serileri arasında bile fark vardır. Bu yüzden biyobenzerler aynı olamaz.

3. Biyobenzerlerin hekim inisiyatifi dışında birbirinin yerine kullanılması. Bu durumun sorun teşkil edeceğine dair açık kanıtlar olmamasına rağmen biyobenzerlerin birbirinin yerine kullanılması etkinlik ve yan etki takibinde sorun yaratacağından önerilmemektedir. Etkinlik ve yan etkiler ile ilişkili hasta bilgilendirilmeli ve hasta tercihi önemsenmelidir. İlaç değişimi durumunda ise, ilaçla ilişkili ya da ilişkisiz olumsuz sonuçlar hukuksal sorunlar yaratabilir. $\mathrm{Bu}$ durum nedeniyle de hekim inisiyatifi dışında değişim yapılmamalıdır.

4. İhalelerde hastane eczanelerine orjinatör yerine biyobenzerini alma zorunluluğu olabilir mi? İhale kurallarının biyobenzerlere göre güncellenmesi gerekmektedir. Hekim inisiyatifi dışında biyobenzerler arasında değişim engellenecekse jenerik ilaçlara uygulanan ihale kuralları da biyobenzerlere uygulanamaz. Her bir biyobenzerden eczanede bulundurulmalıdır. Bugün için Avrupa İlaç Ajansı (EMA, European Medicines Agency), Avrupa Birliği ülkelerinde hekim inisiyatifi dışında ilaç değişimini önermemekte ya da izin vermemektedir.

5. Farklı biyobenzerler hastada bir arada kullanılabilir mi? Bu şekilde bir kullanım kesinlikle önerilmemektedir. Bu nedenle serbest eczaneler ya da hastane eczanesinde her biyobenzerin her bir formu bulundurulmalıdir.

6. Biyobenzerler ile orjinatörü karşılaştıran klinik çalışmalar etik midir? Maliyet etkinlik kavramının getirdiği zorunluluklar içinde etik değildir denilemez. Ancak hasta bilgilendirilmesi sırasında klinik çalışmanın amacının daha iyi bir sonucu hedeflemek olmadığı vurgulanmalıdır. Biyobenzerin daha iyi olabileceğini araştıran çalışmalar "superiority" çalışmalar olmalıdır ki bu durumda biyobenzer ilaçtan ziyade yeni bir ilaçtan bahsetmek gerekir. Biyobenzer çalışmaları genellikle "non-inferiority" çalışmalarıdır $(2,7)$.

7. Hastalar ilaç güvenilirliğinin karşılaştırılması açısından tedavi boyunca ve sonrasinda en az 6 ay izlenmeli ve uygulanan ilaçlara ait farmakovijilans ve risk yönetimi planları yapılmalıdır (8).

\section{İmmunojenisite}

Biyofarmasötiklerin özellikle de biyobenzerlerin kullanımı ile ilişkili en güncel ve önemli konulardan biri de immunojenisitedir. Protein dizayn ve sonrasındaki konformasyonel değişiklikler, safsızlık, kullanılan yardımcı maddeler, üretim ve ambalajlamadaki her basamak, ilacın yitiliğii, veriliş yolu, sıklığı, süresi, ayrıca immünolojik yanıtın baskılanması ve beraber kullanılan ilaçlar gibi hastaya ait özel değişkenler immunojenisiteyi etkileyebilir. Dolayısıyla ilaç geliştirilme sürecinde immunojenisite riskinin en aza indirilmesi ve klinik uygulamalarda takibi biyofarmasötikler için en temel sorunlardandır.

Bir antikor bağlanma yerine ya da T-hücre reseptörüne 
spesifik olarak bağlanabilen maddelere antijen ve bu bağlanma sonucunda humoral ya da hücresel yanıt oluşturan antijene de immunojen denir. Her immunojen antijen ancak her antijen immunojen değildir. Özellikle yüksek ağırlıklı proteinlerde kompleks konformasyonel yapı ve farklılaşmış glikoproteinler, posttranslasyonel modifiye yan zincirler antijenik yerlerdir ve immunojen olabilirler. Immunojenisite, bir antijenin hapten-taşıyıcı ilişkisi, epitop (antijenik özelliği belirleyen bölge) parçasının ikincil, üçüncül, dördüncül yapılar içinde konumlanması, eklenen yan zincirler vs ilişkili çok sayıda faktöre bağlı olabilir (Tablo 1) $(5,9-11)$.

Tablo 1. İmmunojenisiteyi Etkileyen Üretim süreci ve İlaçla İlişkili Faktörler

\begin{tabular}{l}
\hline 1- Primer Yapı \\
2- Agregatlar \\
3- Katkı Maddeleri \\
4- Yabancı Maddeler \\
5- Posttranslasyonal modifikasyon \\
6- Degradasyon ve yeni epitoplar \\
7- Glikolizasyon \\
8- Ürünün ve proteinin kendisine yardımcı CD4 ${ }^{+}$ya da B \\
hücre epitoplarının varlığı \\
\hline
\end{tabular}

Her biyofarmasötik bir antijendir ve immunojen olup olmayacağ1 veya ne kadar immunojen olacağ1 üretim sürecindeki her basamakta çok sayıda faktörden etkilenmektedir (Tablo 2).

Tablo 2. İlaç Geliştirme ve Üretim Sürecinde İmmunojenisite

\begin{tabular}{l} 
1- Ürün Gelişimi \\
\hline a. Protein dizaynı \\
b. Preklinik gelişim \\
c. Klinik gelişim \\
\hline 2- Üretim Süreci \\
\hline a. Üretim sistemi seçimi \\
b. Hücre kültürü ve kurtarma sistemi tasarımı \\
c. Formülasyon gelişimi \\
d. Karakterizasyon, biyoeşdeğerlik, stabilite, toksikoloji \\
çalışmaları \\
e. Ambalajlama yöntemi \\
f. Ticari Üretim
\end{tabular}

Biyoterapötik ürün ve süreç gelişimi aşamalarında immunojenisite değerlendirmeleri çok yönlü ve son derece ayrıntılıdır (Şekil 4) (12).İmmünojenisite ürün güvenliğinin ve ürün kalitesinin önemli bir ölçütüdür. Bununla beraber güvenlik açıkları ya da güvenlik açığı endişesi kaçınılmazdır. Tüm bunlardan dolayı farmakovijilans büyük bir öneme sahiptir. Biyobenzerlerin adlandırılması ve reçetelenmesi kurallarla belirlenmeli, kılavuzlara uyulmalıdır (13).

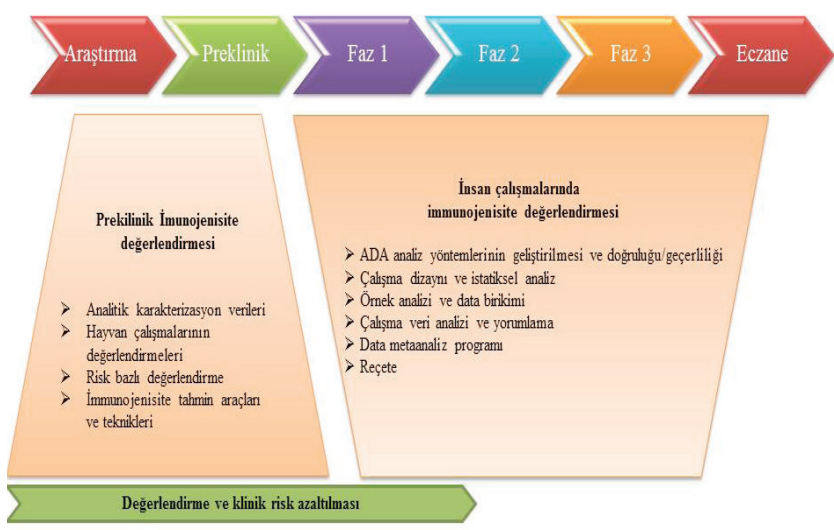

Şekil 4. İlaç geliştirme ve üretim sürecinde immunojenisite riskinin değerlendirilmesi

İmmunojenisite biyofarmasötiklerin güvenlik ve etkinliklerini belirleyebilen en önemli faktörlerdendir (Tablo 3).

Tablo 3. İmmunojenisitenin Klinik Sonuçları

\section{1- Güvenlik}

a. Hipersensitivite veya anaflaktik reaksiyonlar

b. Eksiklik sendromu

c. İmmun kompleks formasyonu

\section{2- Etkinlik}

a. Terapötik proteinin aktivitesinin nötralizasyonu

b. Yarı ömrün kısalması veya uzamasıyla etkinlik üzerine arttırıcı veya azaltıcı rolü

c. Değişen biyoyararlanımın etkinliğinin artması veya azalması

d. Farmakokinetik yayılım veya yarı ömrün kısalması

e. Biyodağılımın değişmesi

f. PK değişiklikleri doz ayarında değişimleri gerektirebilir.

\section{3- Diğer}

a. Gözle görülür hiçbir etki yok 


\section{Biyobenzer İlaçlarda Maliyet, Etkinlik ve Klinik Çalışmalar}

EMA ve FDA (Food and Drug Administration)'da onaylanan biyobenzer ürünler Tablo 4'de listelenmiştir. Pek çok biyofarmasötiğin patent süresinin bitmiş ya da bitmek üzere olması bu sayıı arttıracaktır (14). Türkiye'de ise,

$\checkmark$ Filgrastim,

$\checkmark$ Epoetin zeta,

$\checkmark$ Epoetin alfa,

$\checkmark$ Somatropin,

$\checkmark$ Enoksaparin $\mathrm{Na}$,

$\checkmark$ Absiksimab,

$\checkmark$ İnfliksimab, 2014 yılı itibariyle ruhsat almış biyobenzerlerdir (14).

Tablo 4. EMA ve FDA' da onaylı biyobenzer ürünler

\section{Filgrastim}

Somatropin

Epoetin alfa

Epoetin zeta

İnfliksimab

Follitropin alfa

İnsülin glarjin

Biyolojik ürünlerin dünyada yıllık satı̧ tutarının 2015 yılı itibariyle 200 milyar dolar olması beklenmektedir. Bu durum hem kamu finansmanı açısından önemli bir yük hem de birçok şirket için önemli bir pazar anlamına gelmektedir. Biyobenzerlerin tamamen ayrı ilaç kabul edilerek benzeri oldukları orijinal molekül gibi tüm aşamalardan geçerek ruhsatlanması maliyet avantajı oluşturmaz ki biyobenzerlerin varlığının temel amacı biyofarmasötik ilaçların maliyetini düşürmektir. Biyobenzerlerin geliştirilme sürecinde klinik çalışmalar daha sınırlı tutularak ve "ekstrapolasyon" ile maliyetler düşürülmeye çalışılmaktadır. Her endikasyonda çalışma yapılmaması, faz çalışmalarının bazılarının şart koşulmaması ve çalışması olmayan endikasyonlarda "ekstrapolasyon" ile onay alınması var olan endişeleri artırmaktadır.

EMA; fizikokimyasal benzerlik ve yapisal benzerlik tanımlanması durumunda biyobenzerlerin orjinatöre benzer klinik etkinlik gösterebileceğini vurgulamaktadır. Dolayısı ile belli hassas hedeflerle etkinlik ve güvenlik verilerinin elde edilebileceğini varsaymaktadır. Ana sonlanım noktalarının birincil sonlanım noktası olmadığı (örnek kanserli hastalarda progresyonsuz ve genel sağkalım sonuçları gibi) ancak, bu sonuçları iyi tanımlanmış hassas kriterlerle (örnek meme kanserinde lokal evrede neoadjuvant tedavi ile tam yanıt oranı) gösterebilen çalışmalar EMA tarafından önerilmektedir. Orjinator ürünün geliştirilmesi ve onay sürecindeki gibi klasik çalışmaların yapılması durumunda hem maliyet avantajı oluşmayacak hem de daha kısa ve basit olarak gösterilebilecek güvenlik ve etkinlik çalışmalar varken silbaştan çalıșmaların etik olmayabileceği vurgulanmaktadır. Dolayısı ile biyobenzer ilaçlarla yapılacak klinik çalışmalarda üçönemli noktaya dikkat çekilmektedir;

1. Sonuçları en iyi yansıtacak homojen hassas hasta populasyonunda çalışmanın yapılması,

2. Orjinatör ilaçların klinik etkinliğine benzer sonuçlara sahip olduğunu gösterecek hassas sonlanım noktaları,

\section{Güvenlik-immunojenisite verileri.}

Homojen hassas hasta popülasyonu tanımı son derece önemlidir; meme kanserli hastalar düşünüldüğünde herhangi bir kemoterapi almamış, olası komorbiditeleri daha az ve daha önce kemoterapi ile bağışıklık sistemi ve organ rezervleri etkilenmemiş, hastalık yaygınlığı açısından oldukça benzer olan erken evre meme kanserli hastalar hassas hasta popülasyonu için oldukça uygun bir gruptur. Fakat metastatik evre kanserli hastalar, organ rezervleri ve hastalık yaygınlığı, komorbit ek sorunlar ve immun sisteminin önceki tedavilere ve hastalığa bağlı etkilenmiş olabileceğinden dolayı homojen hassas hasta popülasyonu tanımı için uygun görülmemektedir. Dolayısı ile metastatik hastalarda yapılan ve sonuçların indirekt karşılaştırıldığı çalışmaların sonuçları uygun olmayabilir.

Yine erken evre meme kanserinde neoadjuvan kemoterapiye tam yanıt, sağkalım sonuçlarını iyi tahmin eden hassas bir sonlanım noktasıdır. Oysa homojen ve hassas popülasyon olmayan metastatik kanserli hastalarda tümörün tedaviye yanıtları sağkalım sonuçlarını sağlıklı tahmin etmeyebilir ve biyobenzer çalışmalarda sonlanım noktası olarak kullanılmaları sağkalım sonuçlarını temsil etmeleri açısından yeterli olmayabilir.

Biyobenzer çalışmalarda amaç orjinatörle karşılaştırabilirlilik olduğu için EMA, çalışmaların "equivalence" ya da "noninferiority" şeklinde dizayn edilmesini önermektedir. $\mathrm{Bu}$ çalışmalarda istatistiksel olarak "equivalence" ya da "noninferiority" sınırlarının belirlenmesi de ayrıca önemlidir. 
Sınırlar geniş tutulursa daha az hasta sayısı ile çalışmalar yapılabilir ancak bu çalışmaların orjinatör ile biyobenzer ürünün benzer etkinliğe sahip olduklarını gösterme gücü azalabilir. Sınırlar dar tutulursa çalışmalardaki hasta sayısı yükselir bu da arzulanan maliyet düşüşüne engel olabilir (Şekil 5) (7, 15-17).

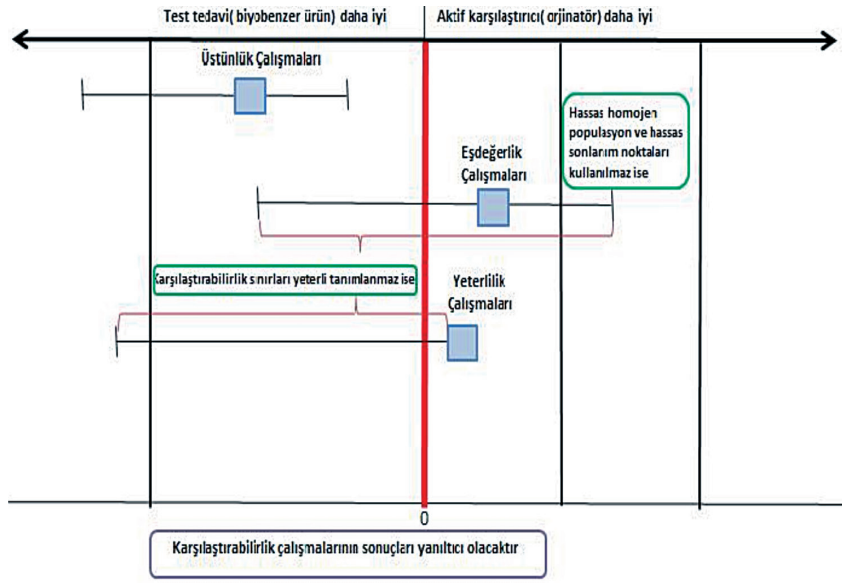

Şekil 5. Biyobenzer ilaç çalışmalarında çalışma tasarımı: Biyobenzer çalışmalarda amaç orjinatörle karşılaştırabilirlik olduğu için bu çalışmalarda istatistiksel olarak sınırların belirlenmesi önemlidir. Eğer hassas homojen populasyon ve hassas sonlanım noktaları kullanılmaz ise, karşılaştırabilirlik sınırları yeterli tanımlanmaz ise, karşılaştırabilirlik çalışmalarının sonuçları yanıltıcı olur (14).

Biyobenzerlerin orijinatörle karşılaştırabilir olduğunu araştıran ve ilaç maliyetini düşürmek için daha az hasta ve zamanda yapılmasını hedefleyen biyobenzer çalışmalar, sağlık otoriteleri açısından üzerinde titizlikle durulması gereken bir konudur. Maliyet hedefi ön plana çıkarıldı̆̆ında etkinlik ve güvenlik sorunları ortaya çıkabilir. Etkinlik ve güvenlik kaygılarının öne çıkması arzulanan maliyet avantajının ortaya çıkmasını engelleyebilir.

EMA tarafından uygulanabilir olduğu belirtilen biyobenzer ilaçlarda maliyeti düşürmenin yöntemlerinden biri de ekstrapolasyon yani endikasyon genişletmedir. Ekstrapolasyon ilaçların etki mekanizması açık şekilde bilindiği durumlarda, belli endikasyonlarda orjinatörle biyobenzerin karşılaştırılabilir olduğunu gösterdikten sonra orjinatörün diğer endikasyonlarda çalışma yapılmaksızın biyobenzer ürünün ruhsatlandırılması olarak tanımlanabilir (2).

Ekstrapolasyon ile birçok endikasyonda çalışma yapma şartı ortadan kalktığı için ilaç maliyetinde belirgin düşüş sağlanabilir. Ancak, aynı olmayan fakat belli endikasyonlarda karşılaştırılabilir etkinlik ve güvenliğe sahip ilaçların kanserin her evresinde aynı etki gösterip göstermeyeceği tartışmalıdır (Şekil 6).

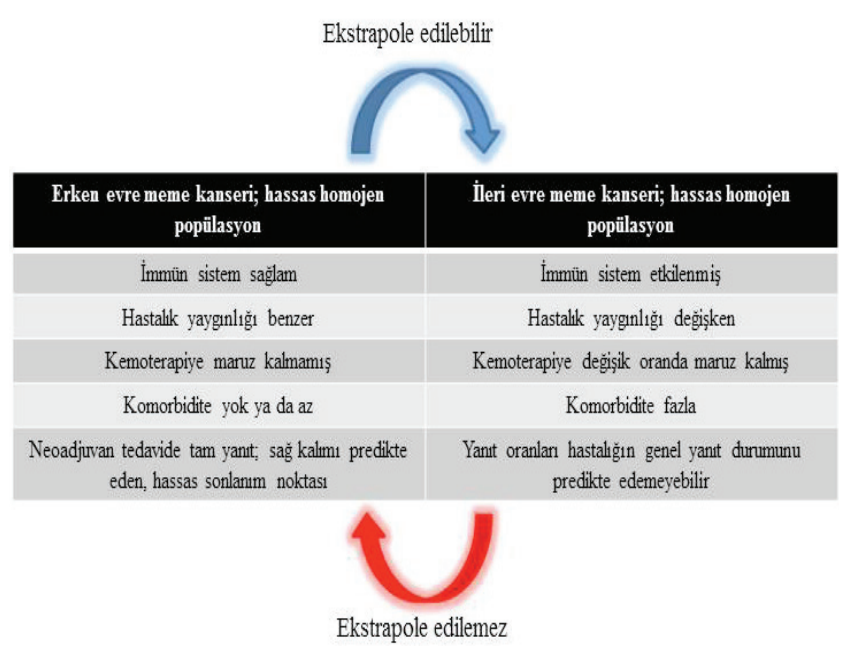

Şekil 6. Biyobenzer ilaçların erken evre ve ileri evre kanserde karşılaştırılabilirliliği: Erken evre meme kanserinde endikasyon almış bir biyobenzer ileri evre meme kanseri için ektrapole edilebilir ancak ileri evre meme kanseri endikasyonu olan biyobenzerin erken evre meme kanserin için ekstrapole edildiğinde aynı etkiyi gösterip göstermeyeceği tartışmalıdır.

Ekstrapolasyon'a ve klinik çalışmaların sadeleştirilmesine rağmen biyobenzerlerin hem hastalar hem de hekimler tarafından yeterince kabul görmemeleri ve kullanılmaması beklenen maliyet azalmasına engel olabilir. Diğer yandan bir kanser türünde orjinatöre benzer etkinlik ve güvenlik sonuçlarına sahip biyobenzerin diğer kanser türlerinde de aynı sonuçlara sahip olup olmadığı tartışmalıdır (Şekil 7).

\section{Trastuzumab \\ HER-2 (3+) \\ $(2+\mathrm{ISH}+)$}

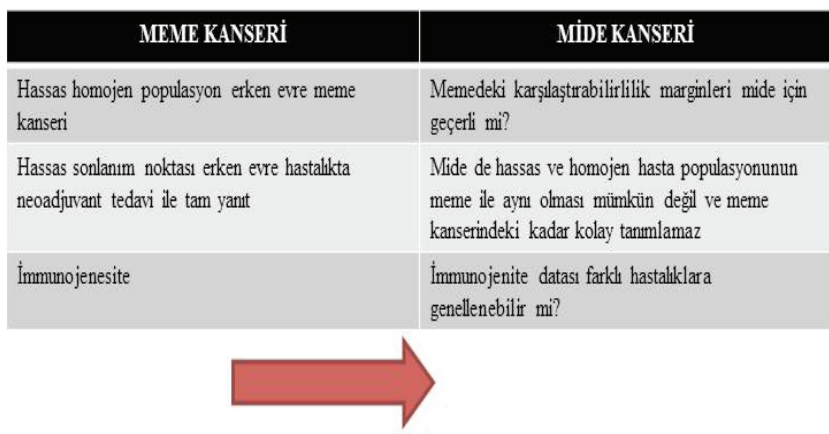

İnfliksimab'a benzer șekilde ekstrapole edilecek ise;

Şekil 7. Meme kanserinde kullanılan transtuzumab infliksimab’a benzer şekilde ekstrapole edilirse etkinlik ve güvenlik sonuçlarının mide kanseri içinde aynı sonuçlara sahip olup olmayacağı tartışmalıdır. 
Amerika’da analitik çalışmalar, orjinatör ile biyobenzer ürün arasında anlamlı farklılıklar olmadığının gösterilmesinde önemsenmektedir. FDA, ürün kalitesi ve orjinatöre benzerlik için iki ürün arasında "yeterli benzerliğin ne kadar benzerlik" olduğunu saptamaya yönelik basamaklı bir yaklaşım önermektedir. Bu görüş ürün performansı hakkında önemsiz farklılıkları azaltma ihtiyacına yönelik klinik ve hayvan çalışmalarını sınırlandırmayı amaçlamaktadır. Orjinatör ürünün geliştirilme sürecinde çok detaylı immunojenisite ve diğer özellikleri inceleme ihtiyacı varken biyobenzerlerde bu sorunlar farmakodinamik, farmakokinetik ve geniş ürün karakterizasyonu ile araştırılabilir. Maliyeti düşürmede bir başka yöntem olan ekstrapolasyonla ise hastaların klinik çalışmaların risklerine maruz kalmasının önüne geçilebilir. Biyobenzer teknolojisindeki gelişmeler ile, bu ürünlerin hastalarda klinik çalışma ihtiyacını azaltacağı düşünülmektedir (18).

\section{Karşılaştırılabilir Olmayan Kopya Ürünler (Non- Comparable Products)}

Biyobenzer ürünlerin hem geliştirilmesi hem de klinik çalışmaların yapılması sürecinde orjinatör ürüne benzerliği, sağlık otoritelerinin belirlediği bilimsel ve kalite kuralları gereğince gösterilir. Birçok ülkede ve çok sayıda üretici tarafından orjinatör ürünün referans alınarak geliştirilmesi ve üretilmesi söz konusu olan ancak, gerekli bilimsel ve kalite kontrollerinin olmadığı biyolojik kopya ürünler vardır. $\mathrm{Bu}$ ürünler yeterli bilimsel kanıt olmadan ve gereklilikleri yerine getirilmemeden biyobenzer olarak tanımlanmamalıdırlar. Bu biyolojik ürünler;

1. İlgili ülkelerde biyobenzerler ile ilişkili gereklilikler sağlık otoritesi tarafından tanımlanmadan önce üretilmiş ve onay almış olabilirler.

2. İlgili ülkelerde biyobenzerler ile ilişkili gereklilikler sağlık otoritesi tarafından tanımlanmasından sonra alternatif yol ya da kestirme yollarla üretilmiş ve onay almış olabilirler.

3. Biyobenzerler ile ilişkili gereklilikler sağlık otoritesi tarafından tanımlanmamış ülkelerde uluslararası geçerli rehberlere uygun olmadan geliştirilmiş, üretilmiş ve onay almış ürünler olabilirler. Benzerlik çalışmaları yoktur.

Karşılaştırılabilir olmayan biyolojik kopya ürünlerin biyobenzer olarak tanımlanmaması ve bu konuda hekim ve sağlık otoritelerin daha dikkatli olması gerekir.

\section{SONUÇ}

Biyofarmasötik ilaçların pazar payları her geçen gün artmaktadır. Tedavide daha sık kullanılır hale gelen bu ilaçların üretilmesinde ve klinik çalışmaların yapılmasında EMA’nın belirlediği kılavuzlara uyulmalıdır. Klinik uygulamalarda sağlık otoriterleri maliyet, hasta yararı, belirsizlikler dengesini iyi kurmalıdır.

\section{Potential problems of biosimilars in clinical practice}

\begin{abstract}
Biopharmaceuticals are macro and complex medicines obtained from biological sources using biotechnology. In the production of biopharmaceuticals, due to the use of living organisms and the complex method of production, in different series made by the same manufacturer even consist differences. Thus different manufacturers can produce similar molecules to the originator, "biosimilar" definition is used to indicate these differences. Nowadays biosimilars are used in treatment of many diseases
\end{abstract}

especially cancer, hematologic diseases and endocrine diseases. Using biosimilars in treatment more frequently and enalarge of their market share encourage to produce copies of patent expired products. The objective of studies in the licensing process is to show rather than to prove that biosimilars are better than their originator, in terms of structure, safety and efficiency. Immunogenicity is the biggest problem encountered in clinical practice for biopharmaceutical products and it may affect medicine activity and safety. In clinical practice, health authoritarian should establish well balance of costs, patient benefit, uncertainty.

Keywords: Biopharmaceutics, Biosimilar pharmaceuticals, Immunogenicity, Clinical Practice

\section{KAYNAKLAR}

1. Barbosa MD, Kumar S, Loughrey H, Singh SK. Biosimilars and biobetters as tools for understanding and mitigating the immunogenicity of biotherapeutics. Drug Discov Today 2012;17:1282-8.
2. Weise M, Bielsky MC, De Smet K, Ehmann F, Ekman N, Giezen TJ, Gravanis I, Heim HK, Heinonen E, Ho K, Moreau A, Narayanan G, Kruse NA, Reichmann G, Thorpe R, van Aerts L, Vleminckx C, Wadhwa M, Schneider CK. Biosimilars: what clinicians should 
know. Blood 2012; 120: 5111-7.

3. European Generic And Biosimilar Medicines Association. Biosimilars Handbook. PDF Dökümanı. http://www.egagenerics.com/index.php/ publications/104-publications/ega-publications/34ega-biosimilars-handbook [Erişim Tarihi: 15 Şubat 2015].

4. Kalman-Szekeres Z, Olajos M, Ganzler K. Analytical aspects of biosimilarity issues of protein drugs. J Pharm Biomed Anal 2012;69: 185-95.

5. Chow SC, Liu JP. Statistical assessment of biosmilar products. J Biopharm Stat 2010;20: 10-30.

6. http://www.ema.europa.eu/docs/en_GB/document_ library/Scientific_guideline/2009/09/WC500003927. pdf. EMA PDF dökümanı.[Erişim Tarihi: 24 Mart 2015].

7. Christensen E. Methodogy of superiority vs. equivalence trials and non-inferiority trials. J Hepatol 2007;46: 94754.

8. http://www.ema.europa.eu/docs/en_GB/document_ library/Scientific_guideline/2009/09/WC50000392030.pdf. EMA PDF dökümanı [Erişim Tarihi: 23 Şubat 2015].

9. Kessler M, Goldsmith D, Schellekens H. Immunogenicity of biotherapeuticals. Nephrol Dial Transplant 2006;21: 9-12.
10. Sharma B. Immunogenicity of therapeutic proteins part2: immact of container closures. Biotechnol Adv 2007;25: 318-24.

11. Wang W, Singh SK, Li N, Toler ML, King KR, Nema S. Immunogenicity of protein aggregates-concern and realities. Int J Pharm 2012; 431:1-11.

12. https://www.proimmune.com/ecommerce/pdf_files/ quarmby.pdf. Immunogenecity and biotherapeutic development. PDF Dökümanı [Erişim Tarihi: 15 Şubat2015].

13. Schellekens H. Follow-on biologics: challenges of the 'next generation'. Nephrol Dial Transplant 2005; 20:31-6.

14. Dal $\mathrm{OH}$, Karadoğan $\mathrm{M}$, Sezer $\mathrm{AD}$. Biyobenzerler: Kavramlar ve ruhsatlandırma süreçleri. Marmara Pharm J 2015; 19: 252-8.

15. Lesaffre E. Superiority, equivalence, and non-inferiority trials. Bull NYU Hosp Jt Dis 2008; 66:150-4.

16. Garattini S, Bertele V. Non-inferiority trials are unethical because they disregard patients' interests. Lancet 2007; 370: 1875-7.

17. Europan Medicines Agency. http://www.ema.europa.eu. [Erişim Tarihi: 23 Şubat 2015].

18. FDA. http://www.appliedclinicaltrialsonline.com/fdalooks-limit-clinical-trials-biosimilar-rd. [Erişim Tarihi: 10.12.2015] 